\title{
Growth- and Differentiation-related Enzyme Changes in Cytoplasmic Membranes of Acanthamoeba castellanii
}

\author{
By K. P. PAULS AND J. E. THOMPSON \\ Department of Biology, University of Waterloo, Waterloo, Ontario, Canada N2L $3 G 1$
}

(Received 13 December 1977; revised 13 February 1978)

Enzyme activities of microsomal fractions have been used to examine the behaviour of cytoplasmic membranes during growth deceleration and encystment of Acanthamoeba castellanii. Rough and smooth microsomal protein content increased two- to threefold during the transition from exponential growth phase to stationary phase, but declined again as the organisms encysted. Total activities of rotenone-insensitive NADH- and NADPH-cytochrome $c$ reductases, enzymes associated with endoplasmic reticulum, were two- to fivefold higher in stationary phase organisms than in exponentially growing organisms, but were 10 - to 100 -fold lower in mature cysts. Specific activities of these enzymes in homogenates and rough and smooth microsomal fractions showed the same pattern of change. Homogenate and microsomal activities of alkaline phosphatase, an enzyme known to be present on the contractile vacuole membrane, were highest in exponentially growing organisms, lower in stationary phase organisms and lower still, by at least eightfold relative to stationary phase cells, in mature cysts. The data indicate that during the transition to stationary phase there is extensive proliferation of cytoplasmic membranes which are subsequently broken down as the cells encyst. The changing activities of the cytochrome $c$ reductases can be attributed to this pattern of membrane synthesis followed by breakdown, although there may also be changes in the abundance of functional enzyme molecules on the membranes. The alterations in alkaline phosphatase activity portray the changing status of the membrane system responsible for water expulsion and reflect a less critical need for osmotic control in the cyst than in the trophozoite.

\section{INTRODUCTION}

Acanthamoeba castellanii is a small free-living soil amoeba that can be cultured axenically in liquid medium (Neff, 1957). The organism can exist either in a vegetative amoeboid stage (trophozoite) or in a resting stage (cyst). Transitions between these stages can be achieved with reasonable synchrony under laboratory conditions (Chambers \& Thompson, 1974). Amoebae in culture display an exponential growth phase followed by a growth deceleration phase and finally a stationary phase once the cultures have achieved a population density of between 2 and $3.5 \times 10^{6}$ organisms $\mathrm{ml}^{-1}$ (Wilkins \& Thompson, 1974; Weisman, 1976). Encystment occurs in the event of starvation and can be induced by simply leaving cultures in stationary phase (Weisman, 1976) or transferring organisms at any stage of growth into nutrient-free medium (Neff et al., 1964). In this sense, A. castellanii differs from Entamoeba invadens, for trophozoites of the latter become inactive and lyse rather than encyst when deprived of nutrients (Rengpien \& Bailey, 1975). Encystment of $A$. castellanii can also be induced by adding inhibitors such as ethidium bromide (Jantzen, 1974) or hydroxyurea (Rudick, 1971) to growing cultures of amoebae.

The end result of encystment is the formation of an organism that can withstand prolonged starvation and desiccation, but is capable of only minimal metabolic activity. 
Isolated mitochondria from encysted organisms respire poorly and fail to exhibit respiratory control (Band \& Mohrlok, 1969). Glyoxylate cycle activity is reduced and [hydrolase activities are also very low (Tomlinson, 1967; Neff \& Neff, 1969). Formation of the cyst entails extensive degradation of macromolecules and re-utilization of the resulting metabolites for synthesis of cyst-specific macromolecules, in particular cyst wall material. RNA, protein and glycogen levels all decline, and the organisms decrease in size (Neff \& Neff, 1969; Rudick \& Weisman, 1973). Biochemical and morphological observations suggest that this degradative phase is mediated by lysosomal enzymes (Griffiths \& Bowen, 1969). Autolysosomes can be readily seen once the outer wall forms and they remain prominent throughout encystment (Bowers \& Korn, 1969).

Rotenone-insensitive NADH-cytochrome $c$ reductase (EC 1.6.99.3) and NADPHcytochrome $c$ reductase (EC 1.6.99.1) are associated with rough and smooth microsomal membranes in this organism, whereas alkaline phosphatase (EC 3.1.3.1) is present on the contractile vacuole membranes and in preparations of plasma membrane (Thompson \& Schultz, 1971; Wilkins \& Thompson, 1974). In the present study, these enzymes have been used as indicators of membrane function to assess how growth deceleration and encystment affect the properties of cytoplasmic membranes.

\section{METHODS}

Cultures. Trophozoites of $A$. castellanii (Neff) were cultured axenically in 21 Erlenmeyer flasks containing 1 litre medium (Schultz \& Thompson, 1969). The flasks were inoculated with $2 \mathrm{ml}$ of stationary phase culture and incubated on a rotary shaker $\left(100 \mathrm{rev} . \mathrm{min}^{-1}\right)$ at $29^{\circ} \mathrm{C}$ for $40 \mathrm{~h}$ for exponentially growing cells and for $7 \mathrm{~d}$ for stationary phase cells. Encystment was induced by placing stationary phase organisms in nutrient-free medium as described by Chambers \& Thompson (1972). Cyst cultures ranging in age from 900 to $2200 \mathrm{~h}$ were used for analysis. Viability of the cyst cultures was checked by phase contrast microscopy. Routinely, after more than $2000 \mathrm{~h}$ of incubation in saline, fewer than $1 \%$ of the cells had lost the refractility that characterizes a living cyst.

Fractionation procedures. Rough and smooth microsomal fractions were isolated from exponentially growing organisms, stationary phase organisms and cysts by a procedure described earlier (Thompson \& Schultz, 1971). Cysts were harvested by vacuum filtration through Whatman no. 1 filter paper, resuspended in $0.3 \mathrm{M}$-sucrose (adjusted to $\mathrm{pH} 7.5$ with $\mathrm{NaHCO}_{3}$ ) to make a $10 \%(\mathrm{w} / \mathrm{v})$ suspension and homogenized with a $\mathrm{CO}_{2}$ gas-cooled Braun homogenizer containing glass beads $(1.00$ to $1.05 \mathrm{~mm}$ diam.) for two periods of $15 \mathrm{~s}$ separated by $15 \mathrm{~s}$ cooling. The beads were washed from the homogenate with a small volume of buffer and the suspension was rehomogenized with a Potter-Elvehjem homogenizer (four strokes) before the fractionation was begun. Exponentially growing organisms and stationary phase organisms were harvested from cultures containing $2 \times 10^{5}$ to $6 \times 10^{5}$ organisms ml-1 and $1.6 \times 10^{6}$ to $2 \cdot 8 \times 10^{6}$ organisms ml-1 , respectively, by centrifuging at $800 \mathrm{~g}$ for $5 \mathrm{~min}$, and homogenized as described previously (Thompson \& Schultz, 1971). In each case the $10000 \mathrm{~g}$ supernatant from the fractionation procedure was made $15 \mathrm{~mm}$ with $\mathrm{CsCl}$, layered on $1.3 \mathrm{M}$-sucrose containing $15 \mathrm{mM}-\mathrm{CsCl}, \mathrm{pH} 7.5$, and centrifuged at $120000 \mathrm{~g}$ for $3 \mathrm{~h}$ to obtain the microsomal subfractions. The smooth microsomes collected at the interface of this gradient, although in a few trophozoite preparations the layer at the interface was split into two bands. In such cases the two bands were combined. The rough microsomes formed a layer of loose tan-coloured material immediately overlying a hard-packed colourless pellet at the bottom of the tube and were separated from this hard-packed pellet by gentle agitation. This separation occurred easily and did not disturb the hard-packed pellet. After removal from the gradient, the fractions were diluted with $50 \mathrm{mM}-\mathrm{NaHCO}_{3}, \mathrm{pH} \mathrm{7 \cdot 5}$, and sedimented by centrifugation. These final pellets were resuspended in 1 to $4 \mathrm{ml} 50 \mathrm{~mm}-\mathrm{NaHCO}_{3}, \mathrm{pH} 7 \cdot 5$, and stored at $-20^{\circ} \mathrm{C}$ until required for assays. All enzyme assays were carried out within $2 \mathrm{~d}$ of the fractionation.

Assay procedures. Rotenone-insensitive NADH-cytochrome $c$ reductase and rotenone-insensitive NADPHcytochrome $c$ reductase were assayed at $29^{\circ} \mathrm{C}$ as described by Sottocasa $e t$ al. (1967). The procedure of Bosmann, Hagopian \& Eylar (1968) was used to measure alkaline phosphatase except that the incubation temperature was $29^{\circ} \mathrm{C}$. Protein was measured by the method of Lowry et al. (1951) using bovine serum albumin as a standard. RNA and phospholipid were determined as described by Schneider (1957) and Dittmer \& Wells (1969). 


\section{Table 1. Protein contents of homogenates and microsomal fractions from trophozoites and cysts of Acanthamoeba castellanii}

Protein is expressed as $\mathrm{mg}\left(10^{8} \text { cells }\right)^{-1}$. Standard errors of the means are indicated; $n=4$ to 6 .

\begin{tabular}{lccc}
\multicolumn{1}{c}{ State of differentiation } & Homogenate & $\begin{array}{c}\text { Smooth } \\
\text { microsomes }\end{array}$ & $\begin{array}{c}\text { Rough } \\
\text { microsomes }\end{array}$ \\
Exponentially growing trophozoites & $17 \cdot 4 \pm 1 \cdot 2$ & $0.9 \pm 0.1$ & $0 \cdot 8 \pm 0.08$ \\
Stationary phase trophozoites & $38 \cdot 2 \pm 1 \cdot 4$ & $2 \cdot 1 \pm 0.6$ & $2 \cdot 5 \pm 0.4$ \\
Cysts & $13.9 \pm 2 \cdot 3$ & $0.5 \pm 0.07$ & $0.4 \pm 0.08$
\end{tabular}

\section{RESULTS AND DISCUSSION}

The transition from exponentially growing organisms to stationary phase organisms was accompanied by a doubling in cell protein, but during encystment of stationary phase organisms in nutrient free medium protein levels declined again to a low level (Table 1). This change in protein content is consistent with previous reports (Martin \& Byers, 1976; Barnes \& Jensen, 1967). The protein content of mature cysts was only marginally lower than that of exponentially growing trophozoites and the difference was not significant at the $5 \%$ level. Nevertheless, this still represents a substantial decrease in cytoplasmic protein because the cyst wall, which comprises $37 \%$ of the total dry weight of the cell, is about $33 \%$ protein (Neff et al., 1964).

Changes in microsomal protein accompanying growth inhibition and encystment correlated closely with changes in total cellular protein. Smooth microsomal protein increased by about twofold and rough microsomal protein by threefold during the transition to stationary phase (Table 1). Measurements of protein in these fractions included both membrane protein and any cytosol proteins occluded within the membrane vesicles, but this applied to fractions isolated from both growing and non-growing organisms. In addition, the RNA to phospholipid ratio for the rough microsomal subfraction remained essentially unchanged during growth deceleration, indicating that the increased protein content of this fraction was not due to a greater abundance of ribosomes on the membranes. The rise in microsomal protein is interpreted as reflecting synthesis of cytoplasmic membranes and associated ribosomes. This interpretation is consistent with previous fine structural observations to the effect that conditions leading to encystment result in the formation of intracellular elements resembling endoplasmic reticulum (Byers, Rudick \& Rudick, 1969).

Proteins of both rough and smooth microsomal fractions declined again during encystment (Table 1). The composition of a microsomal fraction is influenced by the homogenization procedure, and the trophozoites and cysts were homogenized by different procedures. However, the procedure used for cysts (Braun homogenizer) is more severe than that used for the trophozoites (Potter-Elvehjem homogenizer) and is likely to have generated more microsomal material. Nevertheless, the rough and smooth microsomal protein contents of cysts were only about $20 \%$ of those for corresponding fractions from stationaryphase organisms (Table 1). Electron microscopy has also revealed that cytoplasmic membranes, in particular endoplasmic reticulum and vacuolar membranes, are less prevalent in cysts than in trophozoites (Bowers \& Korn, 1969). It is therefore apparent that the cytoplasmic membranes of $A$. castellanii proliferate during growth deceleration, only to be disassembled as the cells encyst. Approximately equal amounts of protein were found in each microsomal subfraction of all three stages of development, the combined fractions comprising about $10 \%$ of the total recovered protein.

In order to correlate changes in the abundance of cytoplasmic membranes with alterations in their function, microsomal NADH- and NADPH-linked cytochrome $c$ reductases were measured. The total NADH-cytochrome $c$ reductase activity increased fivefold during the transition from exponential growth phase to stationary phase (Table 2). There was also a 
rise in total NADPH-cytochrome $c$ reductase during this period, but the increase was only just significant at the $5 \%$ level (Table 2). However, total activities of both enzymes were very low in mature cysts (Table 2).

Activities of the enzymes in microsomes followed a similar pattern. For both rough and smooth microsomal fractions NADH-cytochrome $c$ reductase activity rose by about 25-fold and the NADPH-cytochrome $c$ reductase by about sevenfold coincident with the transition to stationary phase (Table 2). The activities then declined again during encystment to levels about $1 \%$ of those for stationary phase organisms (Table 2). This pattern of change was highly reproducible despite variable recoveries of the enzyme activities after fractionation. Recoveries with respect to homogenate were obtained by summing the activities of all the isolated fractions and ranged from 46 to $83 \%$ for the NADH-dependent enzyme and from 31 to $78 \%$ for the NADPH-linked reductase. Microsomal cytochrome $c$ reductases are labile and activities are readily lost in other systems (Siekevitz, 1962).

Patterns of change in the specific enzymic activities of the two cytochrome $c$ reductases of homogenate and microsomal fractions were similar to those observed for total activities of homogenate and microsomal fractions (Table 2), although the increase in homogenate specific activity for NADPH-cytochrome $c$ reductase between exponential phase and stationary phase was not significant at the $5 \%$ level. Alterations in specific enzymic activity of membrane-bound enzymes can provide information about the relationship between changes in enzyme activity and changes in the abundance of membrane bearing the enzyme. The parallel increases in microsomal specific activity and total activity during growth deceleration suggest that the higher reductase activities of stationary phase organisms reflect not only membrane proliferation, but also a greater abundance of active enzyme molecules on the membranes, although the altered specific activities may also reflect differences in composition of the microsomal fractions from exponentially growing and stationary phase organisms. Similarly, although it is clear from microsomal protein content that there is considerable breakdown of cytoplasmic membranes as a result of encystment, the decreased specific activities of the two cytochrome $c$ reductases in the microsomal fractions from cysts suggest that there is inactivation of enzymes independent of membrane disassembly.

Microsomal fractions, particularly the smooth subfraction, are by nature heterogeneous, comprising vesicles of membrane derived from several organelles. Accordingly, to determine the effects of growth deceleration and encystment on cytoplasmic membranes other than endoplasmic reticulum, alkaline phosphatase was also measured. This enzyme is localized on the contractile vacuole of $A$. castellanii (Bowers \& Korn, 1973) and is also present in preparations of plasma membrane by reason of the involvement of the contractile vacuole in water expulsion (Wilkins \& Thompson, 1974). Total alkaline phosphatase activity tended to be lower for stationary phase organisms than for exponentially growing organisms, although this difference was not significant at the $5 \%$ level (Table 3 ). However, microsomal activities decreased by about $50 \%$ for both rough and smooth fractions during growth deceleration (Table 3). Homogenate and microsomal specific activities showed the same trend (Table 3). These data are consistent with a reduced rate of water expulsion in stationary phase trophozoites (Pal, 1972) and also with fine structural observations indicating that the contractile vacuole constitutes a decreasing proportion of the cytoplasmic membrane complement as the cells encyst (Bowers \& Korn, 1969). Recoveries of alkaline phosphatase activity ranged from 89 to $138 \%$ of the activity of homogenates.

Specific activity measurements for alkaline phosphatase also revealed that in preparations from trophozoites the enzyme was enriched by at least threefold in the smooth microsomal subfraction relative to the rough microsomal subfraction (Table 3). This is to be expected since membranes of the water expulsion system are smooth surfaced. However, it is conceivable that highly contracted elements of this membrane system could cosediment with rough microsomes during centrifugation, thus accounting for the presence of alkaline phosphatase in the rough subfraction. 


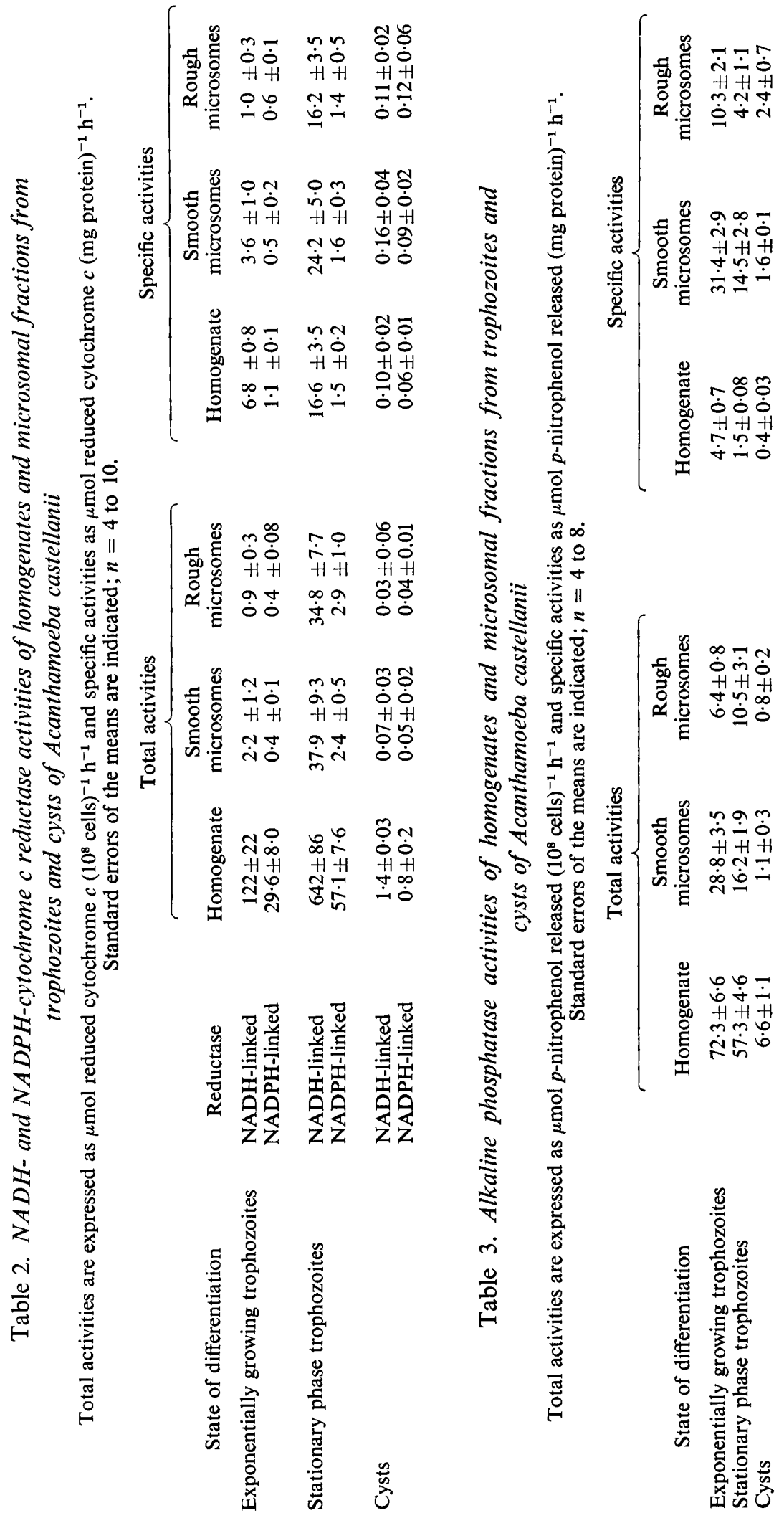


It is apparent, therefore, that distinct types of cytoplasmic membranes, recognizable by the enzymes they possess, behave differently as $A$. castellanii cells pass through stationary phase and ultimately encyst. The separation of rough and smooth microsomes has not been sufficiently critical to distinguish differences in behaviour between rough and smooth endoplasmic reticulum, but it is clear that the membranes bearing cytochrome $c$ reductases and alkaline phosphatase respectively sustain quite different fates. The greatly reduced activity of alkaline phosphatase in mature cysts reflects the less critical need of these cells for osmotic control. The increased activities of microsomal NADH- and NADPH-cytochrome $c$ reductases accompanying growth deceleration in $A$. castellanii are consistent with previous reports of increased function in stationary phase cells including more extensive transcription resulting in the formation of new messenger RNA (Jantzen, 1973), higher levels of cyclic AMP (Gessat \& Jantzen, 1974) and more efficient mitochondrial phosphorylation (Evans, 1973). The very low activities of these enzymes in mature cysts presumably reflect the fact that cysts are essentially dormant cells with only minimal metabolic activity.

\section{This research was supported by the National Research Council of Canada.}

\section{REFERENCES}

BAND, R. N. \& MoHrLoK, S. (1969). The respiratory metabolism of Acanthamoeba rhysodes during encystation. Journal of General Microbiology 59, 351-358.

BARNES, W. \& Jensen, T. (1967). Cytochemical studies of Acanthamoeba castellanii at various stages in its life cycle. Journal of Protozoology 14, suppl. no. 19.

Bosmann, H. B., Hagopian, A. \& Eylar, E. H. (1968). Cellular membranes: the isolation and characterization of the plasma membrane and smooth membranes of HeLa cells. Archives of Biochemistry and Biophysics 128, 51-69.

BowERs, B. \& KoRN, E. D. (1969). The fine structure of Accinthamoeba castellanii. II. Encystment. Journal of Cell Biology 41, 786-805.

Bowers, B. \& Korn, E. D. (1973). Cytochemical identification of phosphatase activity in the contractile vacuole of Acanthamoeba castellanii. Journal of Cell Biology 59, 784-791.

Byers, T. J., Rudick, V. L. \& Rudick, M. J. (1969). Cell size, macromolecule composition, nuclear number, oxygen composition and cyst formation during two growth phases in unagitated cultures of Acanthamoeba castellanii. Journal of Protozoology 16, 693-699.

Chambers, J.A. \& Thompson, J. E. (1972). A scanning electron microscope study of the excystment process in Acanthamoeba castellanii. Experimental Cell Research 73, 415-421.

Chambers, J. A. \& Thompson, J. E. (1974). Agedependent excystment of the protozoan Acanthamoeba castellanii. Journal of General Microbiology 80, 375-380.

Dittmer, J. C. \& Wells, M. A. (1969). Quantitative and qualitative analysis of lipids and lipid components. Methods in Enzymology 14, 482-530.

Evans, D. A. (1973). Growth phase and the number of phosphorylation sites in the mitochondrial electron transport chain of Acanthamoeba castellanii. Journal of Protozoology 20, 336-338.
Gessat, M. \& Jantzen, H. (1974). Die Bedeutung von Adenosin 3',5'-Monophosphat für die Entwicklung von Acanthamoeba castellanii. Archiv für Mikrobiologie 99, 155-166.

Griffiths, A. J. \& Bowen, S. M. (1969). Lysosomal activity and its control in encysting Hartmannella castellanii. Journal of General Microbiology 59, 239-245.

JANTZEN, H. (1973). Änderung des Genaktivitätsmusters während der Entwicklung von Acanthamoeba castellanii. Archiv für Mikrobiologie 91, 163-178.

JANTZEN, H. (1974). Die Entwicklung von Acanthamoeba castellanni zur Cyste mit und ohne Veränderung des Genaktivitätsmusters. Journal of Protozoology 21, 791-795.

Lowry, O. H., Rosebrough, N. J., FARr, A. L. \& RANDALl, R. J. (1951). Protein measurement with the Folin phenol reagent. Journal of Biological Chemistry 193, 265-275.

MARTIN, S. M. \& BYERs, T. J. (1976). Acid hydrolase activity during growth and encystment in Acanthamoeba castellanii. Journal of Protozoology 23, 608-613.

NeFF, R. J. (1957). Purification, axenic cultivation and description of a soil amoeba Acanthamoeba sp. Journal of Protozoology 4, 176-182.

NEFF, R. J. \& NEFF, R. H. (1969). The biochemistry of amoebic encystment. Symposia of the Society for Experimental Biology 23, 51-81.

NefF, R. J., RAY, S. A., Benton, W. F. \& Wilborn, M. (1964). Induction of synchronous encystment in Acanthamoeba sp. Methods in Cell Physiology 1, 56-83.

PAL, R. A. (1972). The osmoregulatory system of Acanthamoeba castellanii. Journal of Experimental Biology 57, 55-76.

RENGPIEN, S. \& BAILEY, G. B. (1975). Differentiation of Entamoeba: a new medium and optimal conditions for axenic encystation of $E$. invadens. Journal of Parasitology 61, 24-30. 
RUDICK, V. L. (1971). Relationships between nucleic acid synthetic patterns and encystment in aging unagitated cultures of Acanthamoeba castellanii. Journal of Cell Biology 49, 498-506.

Rudick, V. L. \& Weisman, R. A. (1973). DNAdependent RNA polymerase from trophozoites and cysts of Acanthamoeba castellanii. Biochimica et biophysica acta 299, 91-102.

SCHNEIDER, W. C. (1957). Determination of nucleic acids in tissues by pentose analysis. Methods in Enzymology 3, 680-684.

Schultz, T. M. G. \& Thompson, J. E. (1969). Enrichment of $5^{\prime}$-nucleotidase in membrane fragments isolated from Acanthamoeba sp. Biochimica et biophysica acta 193, 203-211.

Siekevitz, P. (1962). Preparation of microsomal and submicrosomal fractions: mammalian. Methods in Enzymology 5, 61-68.
Sottocasa, G. L., Kuylenstierna, B., Ernster, L. \& Bergstrand, A. J. (1967). An electron transport system associated with the outer membrane of liver mitochondria. A biochemical and morphological study. Journal of Cell Biology 32, 415-438.

Thompson, J. E. \& Schultz, T. M. G. (1971). Enzymatic properties of microsomal membranes from the protozoan Acanthamoeba castellanii. Experimental Cell Research 68, 106-112.

Tomlinson, G. (1967). The glyoxylate pathway in Acanthamoeba sp. Journal of Protozoology 14, 114-116.

Weisman, R. A. (1976). Differentiation in Acanthamoeba castellanii. Annual Review of Microbiology 30, 189-219.

WiLkins, J. A. \& Thompson, J. E. (1974). The effects of cell population density on the plasma membrane of Acanthamoeba castellanii. Experimental Cell Research 89, 143-153. 